\title{
A comparative study of shell variation in two morphotypes of Lymnaea stagnalis (Mollusca: Gastropoda: Pulmonata)
}

\author{
Maxim V Vinarski
}

\begin{abstract}
Background: Lymnaea stagnalis (L., 1758), the great pond snail, is among the most common and ubiquitous species of aquatic pulmonate gastropods of Palearctic. It is notorious for its enormous conchological variation, and many students tried to separate varieties, subspecies and even distinct species within the L. stagnalis s. I. Recent molecular studies have revealed that there are at least two genetically indistinguishable morphotypes of $L$. stagnalis in Palearctic that earlier were accepted by some authors as biological species under the binomial names $L$. stagnalis s. str. and L. fragilis (L., 1758). In this article, the comparative analysis of their conchological variation in a large physical geographical region (Western Siberia, Asiatic Russia) is provided.

Results: The two morphotypes proved to be rather similar in their ecological preferences, but the patterns of their ontogenic, ecological, and geographical variation look rather distinct as well as the areas of their distribution in Western Siberia. U-shaped body size clines are reported in both morphotypes with the largest individuals tending to occur in the middle (forest-steppe) belt of Western Siberia. The causal analysis of the patterns of geographical variation in conchological traits of the great pond snail has identified the annual precipitation and the length of the growth season as the two main factors to shape the spatial clines in shell size and proportions. Among hydrological parameters, the water flow characteristics (lotic vs. lentic habitats) may influence shell morphology in the great pond snails though ecologically induced variation proved to be rather weak. The differences between populations living under different hydrological regimes may be captured by statistical techniques but are not enough to warrant separation of 'ecological' subspecies or other subspecific categories of ecophenotypic origin.
\end{abstract}

Conclusions: Though there is no doubtless evidence of their specific independence, the two morphotypes, in a sense, 'behave' as two distinct entities with no identical ranges worthwhile to be recognized taxonomically. Their proper position in practical taxonomy should be discussed elsewhere.

Keywords: Distribution; Geographical variation; Polymorphism; Taxonomy; Western Siberia; Morphotypes; Pond snails; Lymnaea stagnalis

\section{Background}

The great pond snail, Lymnaea stagnalis (L., 1758), is a classical model species for studies of different aspects of conchological variation in aquatic pulmonate molluscs (Arthur 1982). It is a very ecologically plastic species able to dwell in a variety of types of inland waterbodies. Its high abundance in waterbodies of different types, ubiquity and very wide (Holarctic) range make it easy to

Correspondence: radix.vinarski@gmail.com

Museum of Siberian Aquatic Mollusks, Omsk State Pedagogical University, 14 Tukhachevskogo Emb, Omsk 644099, Russian Federation collect large samples of individuals of L. stagnalis, and many zoological museums keep large amounts of shells and/or fixed specimens gathered from diverse countries and climatic zones. Besides, the species is well suited to laboratory rearing that allows one to conduct controlled experiments concerning its growth, reproduction, and variation under artificial conditions (Piaget 1929; Kruglov and Starobogatov 1985). The available literature dealing with diverse aspects of biology of this species is positively boundless and cannot be reviewed here even sketchily. 
Most authors who studied variation in natural populations of L. stagnalis, were confident that all examined individuals belong to the same biological species. However, in many localities, pond snails demonstrate wide variability in their shell shapes and to a less extent average sizes. The overall conchological variation in this snail is commonly estimated as 'immense' (Hubendick 1951). In the past, many malacologists tried to convey the variation in shell characters by application of subspecific categories of different rank, most often 'morph' or 'variety'. It should be noted that the two ranks were used rather inconsistently and usually (but not always) were applied to subspecific groups distinguishable on the basis of diverse phenotypic trait (shell size, shell proportions, surface coloration, morphological abnormality and so on). The number of such lower taxa once distinguished within $L$. stagnalis s. 1. is astonishing. For example, the Swedish malacologist Carl Agardh Westerlund (1831-1908) in his famous catalogue of Palearctic continental snails (Westerlund 1885) listed not less than 28 varieties of the great pond snail. Piaget (1929) demonstrated that at least certain of these varieties may well have a hereditary basis. Some workers went much farther and proposed to treat all these numerous varieties as separate 'species' within the 'L. stagnalis group' (Locard 1893). Such an absurdity had pushed other malacologists to opposite extremity - to ignore the conchological variation in this species altogether and to treat it as a highly polymorphic taxon L. stagnalis s. 1. without distinguishing any morphs or even subspecies (Hubendick 1951; Jackiewicz 1998; but see Kruglov and Starobogatov, 1985).

The most recent molecular study has shown that the Palearctic L. stagnalis consists of at least two genetically distinct and geographically separated phylogroups which, however, cannot be discriminated on the basis of morphological characters, either conchological or anatomical (Vinarski et al. 2012a). Nevertheless, it is reasonable to distinguish several well-differentiated morphotypes of the great pond snail, two of them are common in Europe and Siberia. In the system of the family Lymnaeidae proposed by Kruglov and Starobogatov $(1985,1993)$, the two morphotypes are regarded as two 'biological' and thereby reproductively isolated species, namely $L$. stagnalis $\mathrm{s}$. str. and L. fragilis (L., 1758). Though these are obviously dissimilar in their shell shape and proportions (Figure 1), their specific status has not been verified by both electrophoretic studies (Mezhzherin et al. 2008) and genosystematics (Vinarski et al. 2012a).

Externally, the two morphotypes of L. stagnalis s. 1. are quite similar and differ from each other by proportions of their shells, with fragilis morphotype having more slender spire and less inflated body whorl as compared with its counterpart (see Figure 1). The relative body whorl height in stagnalis shells is somewhat higher than in fragilis, and

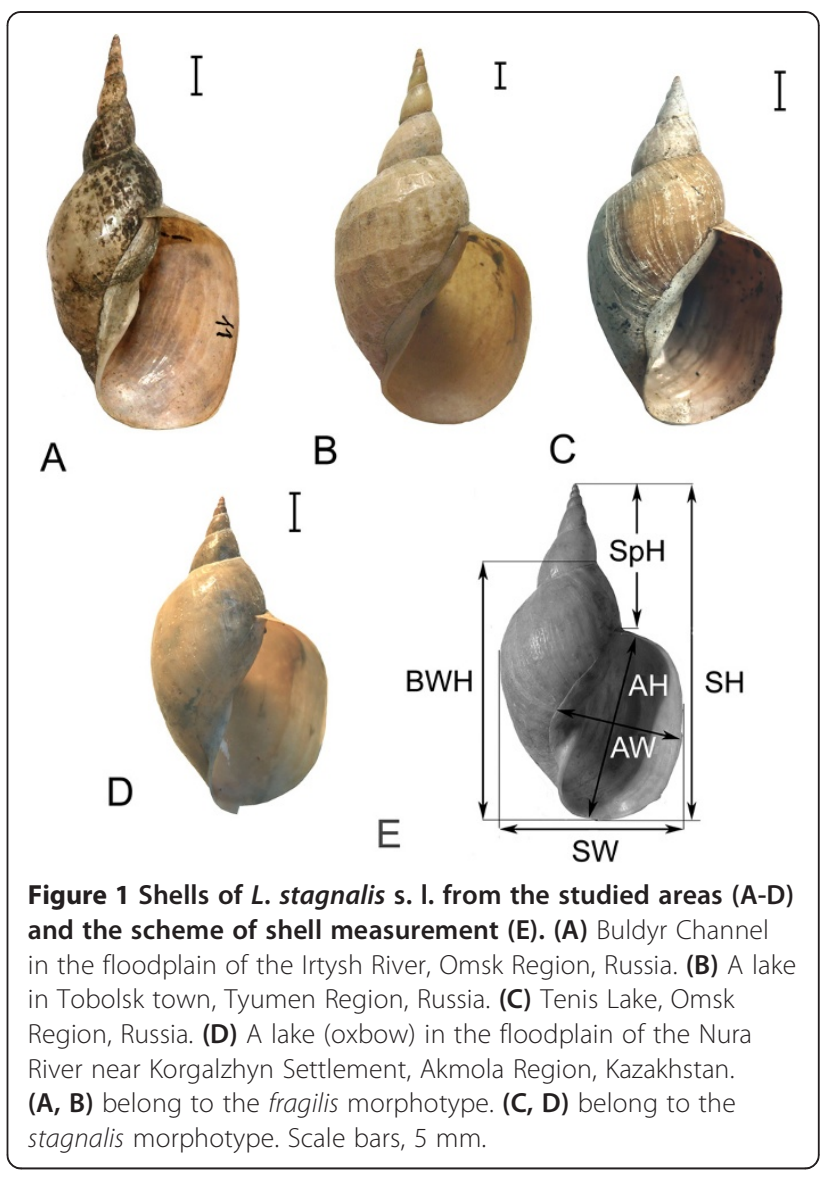

the spire shape of the latter is sometimes almost subulate (see Figure 1A).

In the region of Western Siberia (Asiatic Russia), the two morphotypes are known to co-occur in some microhabitats under the same ecological conditions (Andreyeva et al. 1999, 2010); therefore these do not represent 'ecotypes' in the common meaning of this term. Their nature and specific environmental preferences are still not wholly understood.

The objective of this study is to compare patterns of shell variation in the two morphotypes, $L$. fragilis and $L$. stagnalis s.str., in order to reveal the environmental factors potentially able to modify the conchological characters, as well as to outline their distribution in Western Siberia. The region of Western Siberia was selected for two reasons. First, it has been extensively explored by malacologists, and numerous samples of L. stagnalis s. 1 . from there are available. Second, Western Siberia is a spacious plain where the main environmental gradients (temperature, humidity, seasonality and others) are very well pronounced, and a series of bioclimatic zones, from arctic deserts in north to dry steppes in south, are presented within its boundaries. It makes Western Siberia a very suitable place to study large-scale spatial patterns of morphological variation in molluscs and other animals. 


\section{Methods}

The primary material for this study was presented by 254 samples of L. stagnalis s. $1 .(\mathrm{n} \geq 10$ in each) collected between 1897 and 2013 from the waterbodies of Western Siberia and adjacent territories of the Eastern Urals and south-east of Kazakhstan. The samples are kept in collections of the Zoological Museum of the Institute of Plant and Animal Ecology, Uralian branch of the Russian Academy of Science (Yekaterinburg) and the Museum of Siberian Aquatic Mollusks, Omsk State Pedagogical University (MSAM hereafter). Also, malacological collections of the Zoological Institute of the Russian Academy of Sciences (Saint-Petersburg, ZIN hereafter) and the Zoological Museum of the Moscow State University (ZMMU hereafter) were used. In total, the 254 samples examined contain 11,226 shells of $L$. stagnalis s. l. belonging to the two morphotypes - L. stagnalis s. str. and L. fragilis (see above). Geographical distribution of sampling sites covers all the territory of Western Siberia. The northernmost sample originates from the vicinity of Labytnangi Town $\left(66^{\circ} 39^{\prime} \mathrm{N} 66^{\circ} 24^{\prime} \mathrm{E}\right)$, while the southernmost one was gathered in the Nor-Zaisan Lake, Eastern Kazakhstan $\left(47^{\circ} 52^{\prime} \mathrm{N} 84^{\circ} 49^{\prime} \mathrm{E}\right)$. Thus, the meridional extension of the sampled area exceeds $19^{\circ}$ of latitude.

Identification of morphotypes was carried out by means of keys provided by Starobogatov et al. (2004) and Kruglov (2005). A simplest metric to measure the quantitative relation between the two morphotypes called here as 'fragilisindex' (f-index) was calculated for each locality. F-index is determined as the ratio between amounts of fragilis and stagnalis specimens in a given sample. Its values may range from 0 (all individuals belong to stagnalis morph) to 1 (all specimens in a sample are determined as fragilis).

Shell dimensions were measured following the standard scheme (see Figure 1E) by means of calipers with accuracy to the nearest $0.1 \mathrm{~mm}$. The whorls number was also counted with accuracy to $1 / 8$. Only full-grown, 'adult' shells were used for measurements.

For comparative study of intrapopulational variation in the two morphotypes, I selected 10 large samples collected in large permanent lakes situated in the foreststeppe zone of Western Siberia between $54^{\circ}$ and $58^{\circ}$ of latitude (see in Additional file 1: Table S1). The ecological and geographical proximity of the habitats allows to reduce possible influence of ecophenotypical and geographical variation that is able to bias the results. All these samples are kept in MSAM.

Ecophenotypical variation in shell characters was studied by means of comparison between shell characters of snails collected in waterbodies of different types. Diversity of aquatic habitats in Western Siberia and the number of possible combinations of environmental factors is very high. It is reasonable to reduce this diversity by combining the two most important for pulmonate molluscs hydrological factors, namely, water flow characteristics (lotic vs. lentic habitats) and hydroregime (permanent vs. temporary habitats). Four main types of waterbodies were thus obtained (see Vinarski and Serbina 2012): lotic permanent, lotic temporary, stagnant permanent, and stagnant temporary. Additionally, for the study of the morphotypes ecological preferences, such conventional types of freshwater habitats as 'river,' 'lake, 'pond' and so on were used. Subsequently, the specimens studied were grouped accordingly to types of waterbodies they inhabited using the two schemes.

The most trivial proxy for the overall body size in lymnaeid snails is shell height (Zhadin 1923; Vinarski and Serbina 2012a). It was employed in this study, too, due to its high importance for taxonomic studies and species identification. However, some non-measurable variable would be the best body size estimate since animal size is a multidimensional quantity (Bookstein 1982). To obtain such a variable, I performed principal component analysis (PCA) to combine the information in the conchological parameters studied (see Figure 1E) into a few variables. It is well known that the first principal component (PC1) usually serves as a reliable proxy for the overall size of an animal (Gould and Johnston 1972); therefore the eigenvalues of $\mathrm{PC} 1$ were exploited as the alternative units for statistical analyses.

In order to reveal possible causal relationships between body size and environmental factors, the first PC scores of each sample/morphospecies were related in a multiple regression (forward stepwise analysis) to three spatial variables (latitude, longitude, altitude) and five climatic indicators which, in my opinion, are the most probable predictors of body size variation in aquatic snails: mean annual temperature, mean temperature of the coldest month, annual precipitation, temperature seasonality and precipitation seasonality. The temperature seasonality is calculated as the standard deviation (SD) of the monthly mean temperatures expressed as a percentage of the mean of those temperatures. The precipitation seasonality is defined as the SD of the monthly precipitation estimates expressed as a percentage of the mean of those estimates. The climatic variables for multivariate regression analyses were obtained from the WorldClim database version 1.4 (www.worldclim.org) using Diva-GIS software (http://www.diva-gis.org/).

To assess the environmentally induced variation in the snails, the individual scores of the three first PCs (PC 1-3) of shell measurements were used, and the influence of the factors of locality and waterbody type on PCs was estimated by means of two-sided ANOVA. The number of PCs to be retained was determined by use of the broken stick model of the screen plot. 
The standard methods of statistical analysis, both univariate and multivariate, were used by means of the software packages STATISTICA 6.0 for Windows (StatSoft Inc., Tulsa, OK, USA) and PAST version 2.00 (Hammer et al. 2001).

\section{Results}

Geographical distribution of the morphotypes and patterns of their co-occurrence (syntopy)

In most cases, a particular sample of L. stagnalis s. 1. from the waterbodies of Western Siberia comprises individuals belonging to a single morphotype, either fragilis, or stagnalis. The portion of localities where the two morphotypes co-occur is rather low and does not exceed 25\% (Figure 2). In more than half of samples $(53.1 \%)$ only shells belonging to the morphotype fragilis were found.

The areas occupied by the morphotypes in the region under investigation are not the same. The morphotype fragilis is common throughout almost whole Western Siberia, and its northernmost finding is registered in the southern part of the Yamal Peninsula, between $67^{\circ}$ and $68^{\circ}$ of latitude (Figure 3). On the contrary, the morphotype stagnalis is of apparently southern distribution: the northernmost localities of it studied by me in the field were situated southward of 61 latitude (see Figure 3). Besides, I found 14 shells of stagnalis in a sample (ZIN) collected in 1848 by so called Uralian Expedition and labelled 'Beresov'. Most probably, this locality is identical with Berezovo settlement located in the Ob' River basin at 64 latitude, but this finding is somewhat doubtful since the correctness of the information on labels made by the Uralian Expedition members is assumed to be low (Vinarski 2010). It is not impossible that these specimens might have been collected further south than Berezovo. Interestingly, in the north-eastern part of European Russia (Pechora River basin), the morphotype stagnalis is distributed northward to the Polar circle (see Figure 3).

The dominance of the fragilis morphotype in the northern part of the region is also evident from analysis of spatial variation in the f-index values (Figure 4). These values are moderately but statistically significantly increasing with latitude in Western Siberia. North of 61 latitude all localities have f-index equal to 1.0 (=100\% individuals are fragilis).

Unfortunately, many of museum samples used in this study were not accompanied by full ecological information on their labels; therefore, I could not perform an appropriate analysis to ascertain which ecological conditions may be responsible for observed spatial variation in the fragilis/ stagnalis ratio. I was able only to compare the distributions of the two morphotypes among waterbodies of different types. Generally speaking, they proved to be very close in their ecological preferences and inhabit roughly the same spectrum of waterbodies with clear inclination to dwell in large lakes, rivers and floodplain waterbodies (Figure 5). The occurrences of L. stagnalis s. l. in small temporary waterbodies are also not extremely rare. The bionomic differences between the morphotypes seem to be rather slight. For example, L. fragilis is twice more often registered in floodplain habitats than L. stagnalis, whereas the latter is more frequent in large lakes situated beyond river valleys (see Figure 5). It is noteworthy that most cases (60.3\%) of the morphotype co-occurrence are observed in large lakes, while in rivers and brooks $L$. fragilis and L. stagnalis were found to live together in $4.8 \%$ and $3.2 \%$ of cases, correspondingly.

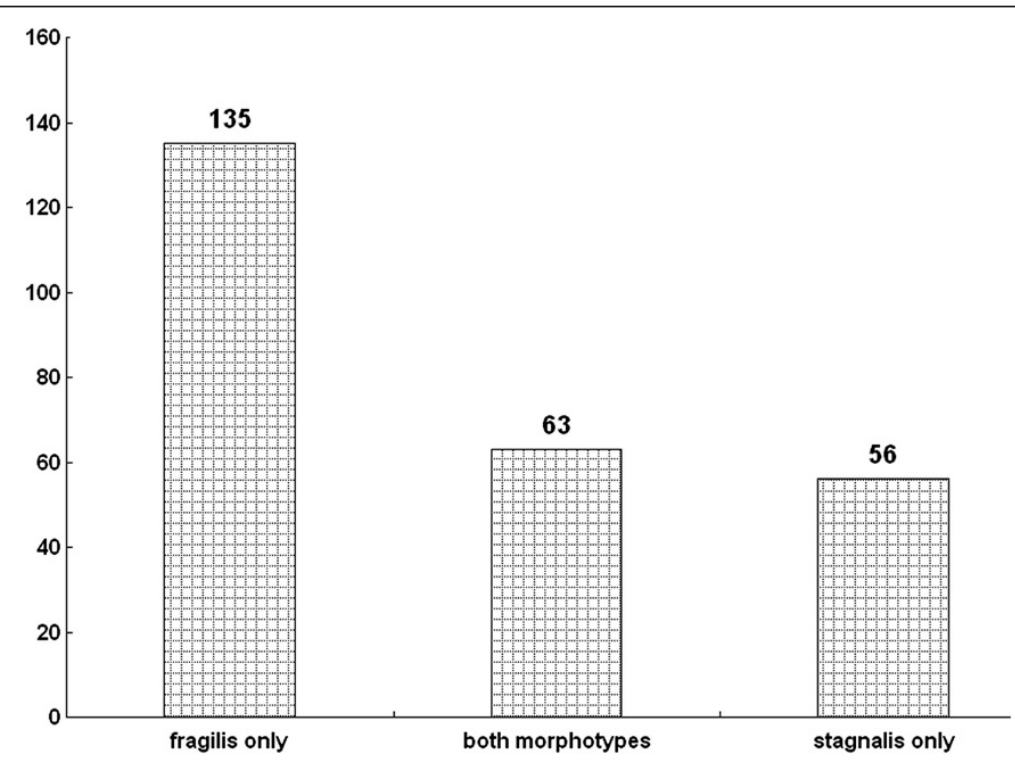

Figure 2 Number of samples containing one or two morphotypes of L. stagnalis s. I. in Western Siberia. 


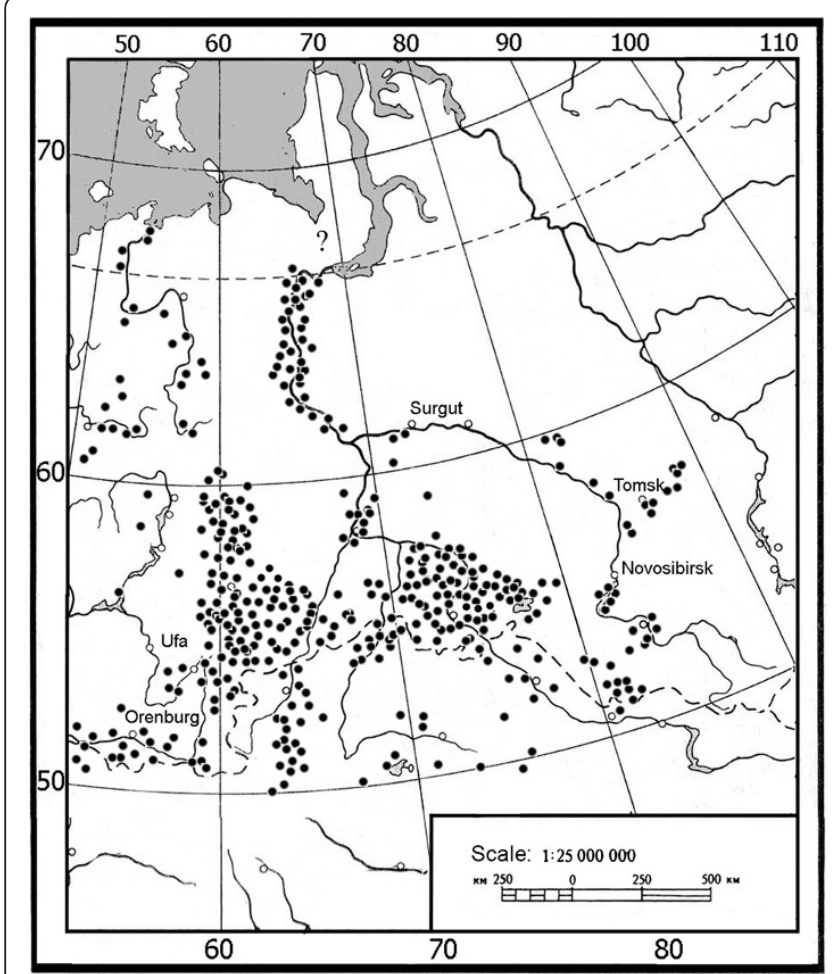

Lymnaea fragilis

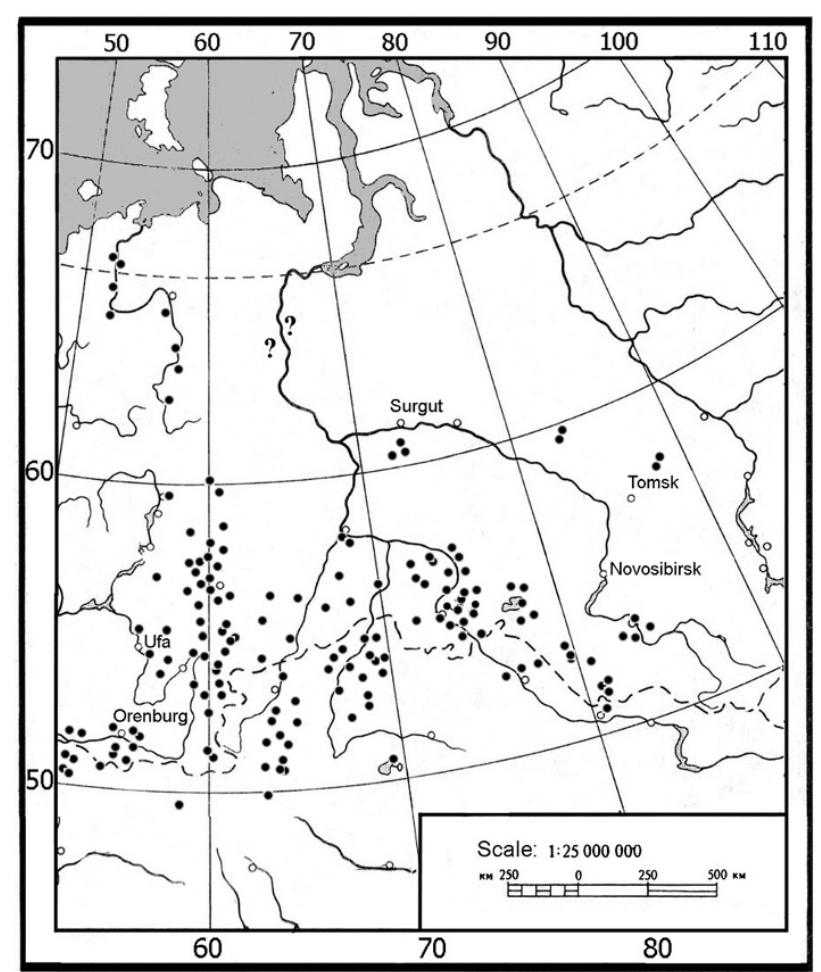

Lymnaea stagnalis

Figure 3 Distribution of the two morphotypes in the Urals and Western Siberia (after M. Vinarski, unpublished).

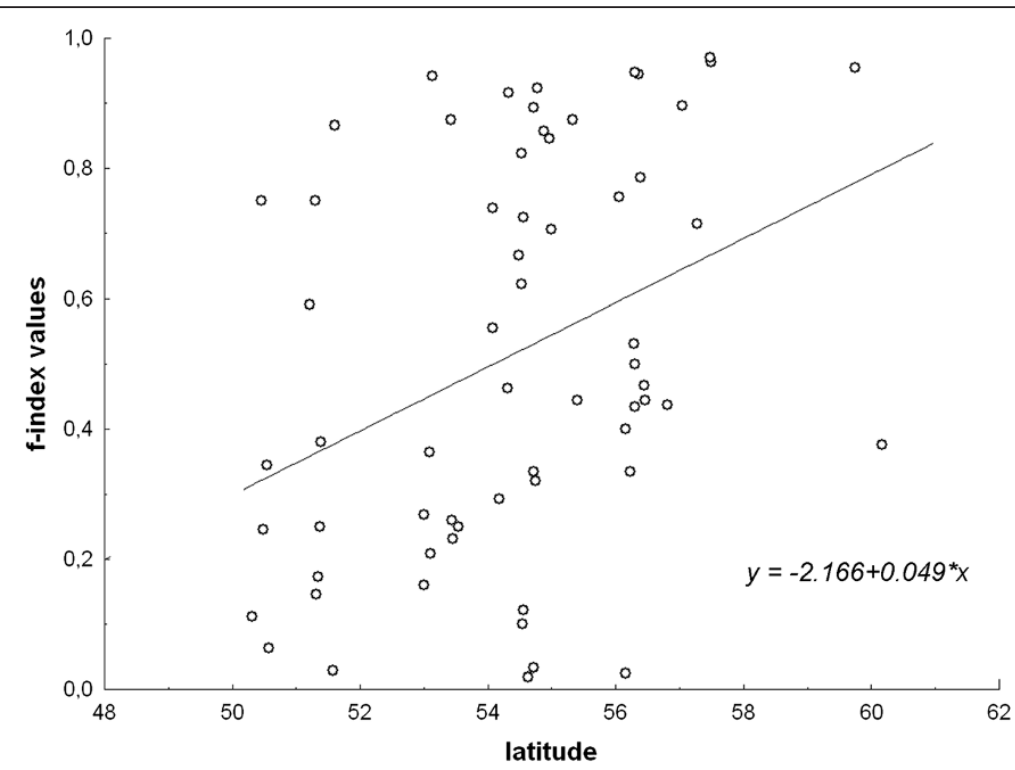

Figure 4 Relationship between geographical latitude and the values of f-index (calculated for all localities where the two morphotypes co-occur). The regression equation is given $\left(R^{2}=0.13, F=9.2, p=0.004\right)$ 


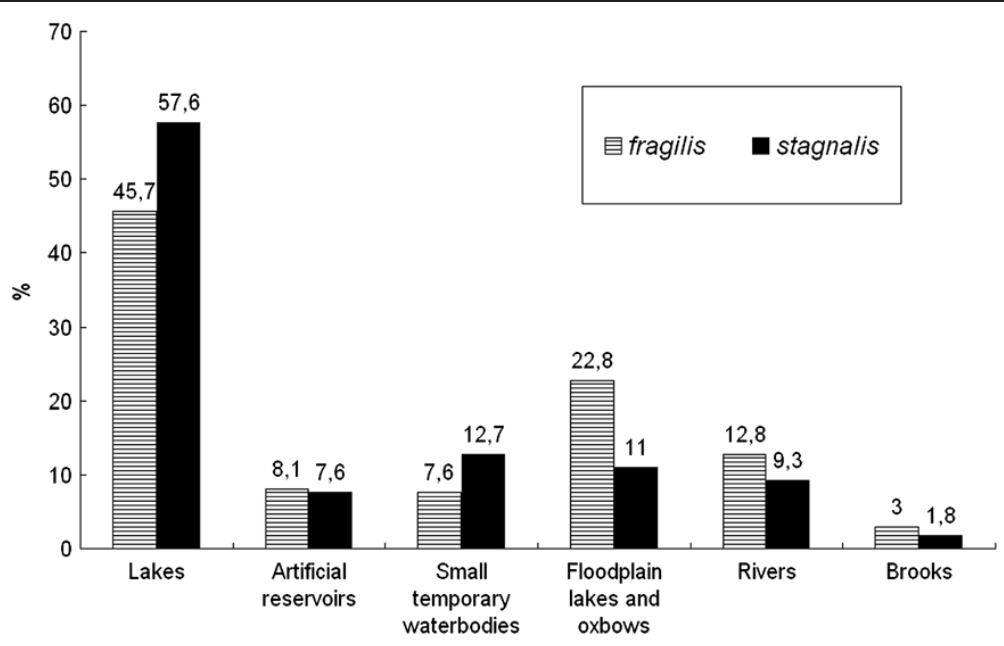

Figure 5 Distribution of the two morphotypes studied in waterbodies of different types.

\section{Conchological peculiarities of the two morphotypes}

The phenotypical differences between the morphotypes described in the 'Background' section are immediately perceptible even without measurements and statistical analyses, and the multivariate techniques allow to discriminate between the morphotypes with high degree of confidence (Figure 6, Table 1). For example, only 22 specimens of $L$. fragilis (or 15.9\%) and 9 specimens of $L$. stagnalis (3.4\%) were wrongly classified by discriminant analysis based on shell measurements (see Table 1). Thus, the average exactness of classification reaches $91.8 \%$.

The mean values of most variables that characterize shell variation in $L$. fragilis and $L$. stagnalis s. str. from a syntopical sample differ significantly (Table 2); however, I am unable to report a clear hiatus in the distribution of character values in the morphotypes (see Table 2, Figure 7). Thus, the reliable discrimination between these morphs is possible only in a case when a large group of individuals is taken into account and several conchological characters are examined simultaneously. The usage of a single measured variable or index may hence be wholly misleading.

The comparative examination of conchological variation in the morphs has shown that the main difference between L. fragilis and L. stagnalis s. str. lies in the patterns of relative growth of their shells, not in shell proportions. The rates of whorls coiling in the two morphotypes are visibly

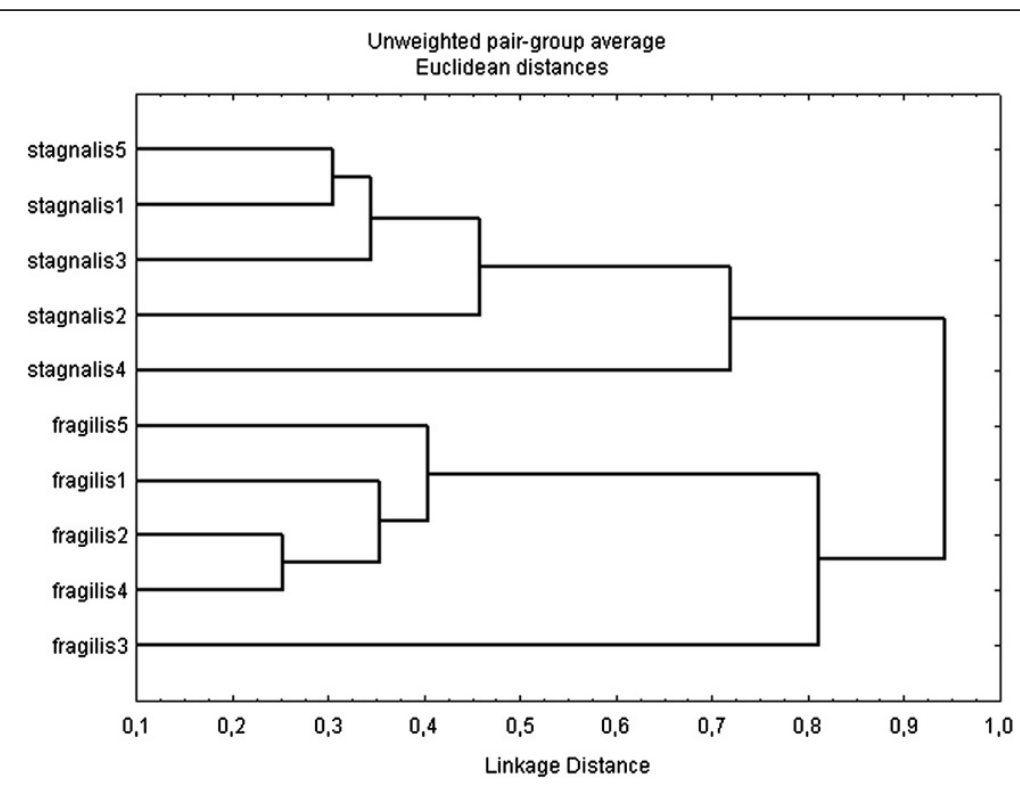

Figure 6 Cluster analysis of samples of $L$. stagnalis s. I. from the forest-steppe lakes of Western Siberia. Based on Mahalanobis distances between them (see in Additional file 1: Table S1 for abbreviations). 
Table 1 Results of the discriminant analysis of the samples listed in Additional file 1: Table S1

\begin{tabular}{|c|c|c|c|c|c|c|c|c|c|c|c|}
\hline \multirow{3}{*}{$\begin{array}{l}\text { Observed } \\
\text { classification }\end{array}$} & \multirow[t]{3}{*}{$\%$ correct } & \multicolumn{10}{|c|}{ Predicted classification } \\
\hline & & \multicolumn{5}{|c|}{ Fragilis } & \multicolumn{5}{|c|}{ Stagnalis } \\
\hline & & 1 & 2 & 3 & 4 & 5 & 1 & 2 & 3 & 4 & 5 \\
\hline Fragilis 1 & 72.2 & 26 & 6 & 1 & 0 & 0 & 0 & 3 & 0 & 0 & 0 \\
\hline Fragilis 2 & 32.3 & 7 & 10 & 1 & 3 & 4 & 1 & 4 & 0 & 1 & 0 \\
\hline Fragilis 3 & 65.5 & 1 & 0 & 19 & 0 & 0 & 5 & 4 & 0 & 0 & 0 \\
\hline Fragilis 4 & 19.0 & 2 & 6 & 3 & 4 & 3 & 0 & 2 & 0 & 0 & 1 \\
\hline Fragilis 5 & 52.4 & 4 & 1 & 1 & 3 & 11 & 0 & 1 & 0 & 0 & 0 \\
\hline Stagnalis 1 & 42.0 & 0 & 0 & 2 & 0 & 0 & 21 & 23 & 4 & 0 & 0 \\
\hline Stagnalis 2 & 81.9 & 0 & 0 & 3 & 0 & 0 & 4 & 95 & 10 & 4 & 0 \\
\hline Stagnalis 3 & 4.0 & 0 & 0 & 1 & 0 & 0 & 4 & 17 & 16 & 2 & 0 \\
\hline Stagnalis 4 & 4.0 & 0 & 0 & 0 & 0 & 0 & 3 & 14 & 1 & 12 & 0 \\
\hline Stagnalis 5 & 0.0 & 0 & 1 & 2 & 0 & 0 & 3 & 19 & 2 & 0 & 0 \\
\hline
\end{tabular}

Most specimens (91.7\%) were correctly classified as belonging to proper morphotypes.

distinct, and the slopes of regression lines describing relative growth of shell height are significantly different when the two samples from the same habitat are compared (Figure 8). Accordingly, shells of L. fragilis and L. stagnalis s. str. with the equal number of whorls demonstrate significant differences in their size and proportions (see Table 2).

\section{Geographical variation in shell size and proportions}

In both morphotypes, the relationship between all size estimates and geographical latitude is non-linear with the largest shells being found between $54^{\circ}$ and $58^{\circ}$ of latitude (Figure 9) that corresponds, in the Western Siberian region, to the forest-steppe bioclimatic zone. In most cases, except of one, these relationships were statistically significant and approximated by polynomial equations. Statistics for the regression equations is given in Table 3. The only climatic variable that correlates significantly with body size both in L. fragilis and L. stagnalis s. str. is the annual precipitation; in L. stagnalis s. str., the factor of geographical longitude is also contributing to the body size variation (Table 4). Temperature in itself seems to be not responsible for latitudinal decrease of body size in both morphotypes.

In the L. fragilis morphotype, the values of all standard conchological indices tend to change gradually with latitude, and the relationships are statistically significant in all cases (Table 5). Since these indices reflect shell proportions, these changes result in clear external differences between specimens of $L$. fragilis collected in the extreme northern and southern populations in Western Siberia (Figure 10). The 'northern' snails have much more slender and high-spired shells than the 'southern' ones, whereas the relative aperture size decreases in the south-north direction.
Table 2 Morphometric characterization of the two morphotypes living syntopically (Tenis Lake, Omsk Region, Russia)

\begin{tabular}{|c|c|c|c|}
\hline \multirow[t]{2}{*}{ Character/index } & \multicolumn{2}{|c|}{ Morphotype $^{a}$} & \multirow[t]{2}{*}{$p$ value } \\
\hline & Fragilis & Stagnalis & \\
\hline \multirow[t]{2}{*}{ Whorls number } & 6.00 to 7.00 & 5.87 to 7.37 & n.s. \\
\hline & $6.67 \pm 0.23$ & $6.56 \pm 0.30$ & \\
\hline \multirow[t]{2}{*}{ Shell height (SH) } & 25.1 to 39.1 & 34.9 to 46.8 & 0.00 \\
\hline & $34.6 \pm 2.9$ & $40.8 \pm 2.7$ & \\
\hline \multirow[t]{2}{*}{ Shell width (SW) } & 11.8 to 19.3 & 17.3 to 24.0 & 0.00 \\
\hline & $17.2 \pm 1.5$ & $20.7 \pm 1.6$ & \\
\hline \multirow[t]{2}{*}{ Spire height (ShH) } & 12.5 to 20.4 & 16.4 to 24.6 & 0.00 \\
\hline & $17.5 \pm 1.7$ & $20.7 \pm 2.0$ & \\
\hline \multirow[t]{2}{*}{ Body whorl height (BWH) } & 17.8 to 29.3 & 26.6 to 35.7 & 0.00 \\
\hline & $26.2 \pm 2.2$ & $31.5 \pm 2.0$ & \\
\hline \multirow[t]{2}{*}{ Aperture height $(\mathrm{AH})$} & 12.2 to 22.1 & 18.9 to 27.3 & 0.00 \\
\hline & $19.7 \pm 1.2$ & $23.7 \pm 1.5$ & \\
\hline \multirow[t]{2}{*}{ Aperture width (AW) } & 9.3 to 13.8 & 11.0 to 22.4 & 0.00 \\
\hline & $12.5 \pm 1.0$ & $14.9 \pm 1.6$ & \\
\hline \multirow[t]{2}{*}{ SW/SH } & 0.45 to 0.58 & 0.46 to 0.56 & n.s. \\
\hline & $0.51 \pm 0.03$ & $0.50 \pm 0.02$ & \\
\hline \multirow[t]{2}{*}{$\mathrm{SpH} / \mathrm{SH}$} & 0.45 to 0.57 & 0.48 to 0.55 & n.s. \\
\hline & $0.51 \pm 0.03$ & $0.51 \pm 0.02$ & \\
\hline \multirow[t]{2}{*}{$\mathrm{BWH} / \mathrm{SH}$} & 0.73 to 0.83 & 0.71 to 0.81 & 0.004 \\
\hline & $0.77 \pm 0.02$ & $0.75 \pm 0.03$ & \\
\hline \multirow[t]{2}{*}{$\mathrm{AH} / \mathrm{SH}$} & 0.50 to 0.70 & 0.51 to 0.61 & 0.048 \\
\hline & $0.58 \pm 0.03$ & $0.56 \pm 0.03$ & \\
\hline \multirow[t]{2}{*}{ AW/AH } & 0.52 to 0.80 & 0.52 to 0.74 & n.s. \\
\hline & $0.63 \pm 0.05$ & $0.64 \pm 0.04$ & \\
\hline
\end{tabular}

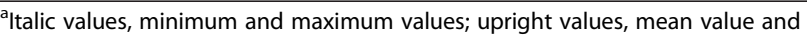
standard deviation ( $\sigma$ ). n.s., non-significant difference between mean values. The significance of differences is checked by Student's $t$ test.

In the L. stagnalis morphotype, all conchological indices except of the relative aperture width (AW/AH) show no significant variation related to latitude (see Table 5).

\section{Ecophenotypical variation}

In both morphotypes, the first three PCs explain more than $95 \%$ of the total conchological variation (Table 6). The first PC is strongly correlated with all linear measurements that are known to increase during ontogeny and, thus, represent the true 'size' variable. PC2 is strongly correlated with the number of whorls and, hence, can reflect the rate of whorls coiling. At last, the third $\mathrm{PC}$ correlates with relative height of spire $(\mathrm{SpH} /$ $\mathrm{SH})$ and relative aperture width $(\mathrm{AW} / \mathrm{AH})$. It may be interpreted as a composite variable related to shell proportions in L. stagnalis s. l. 


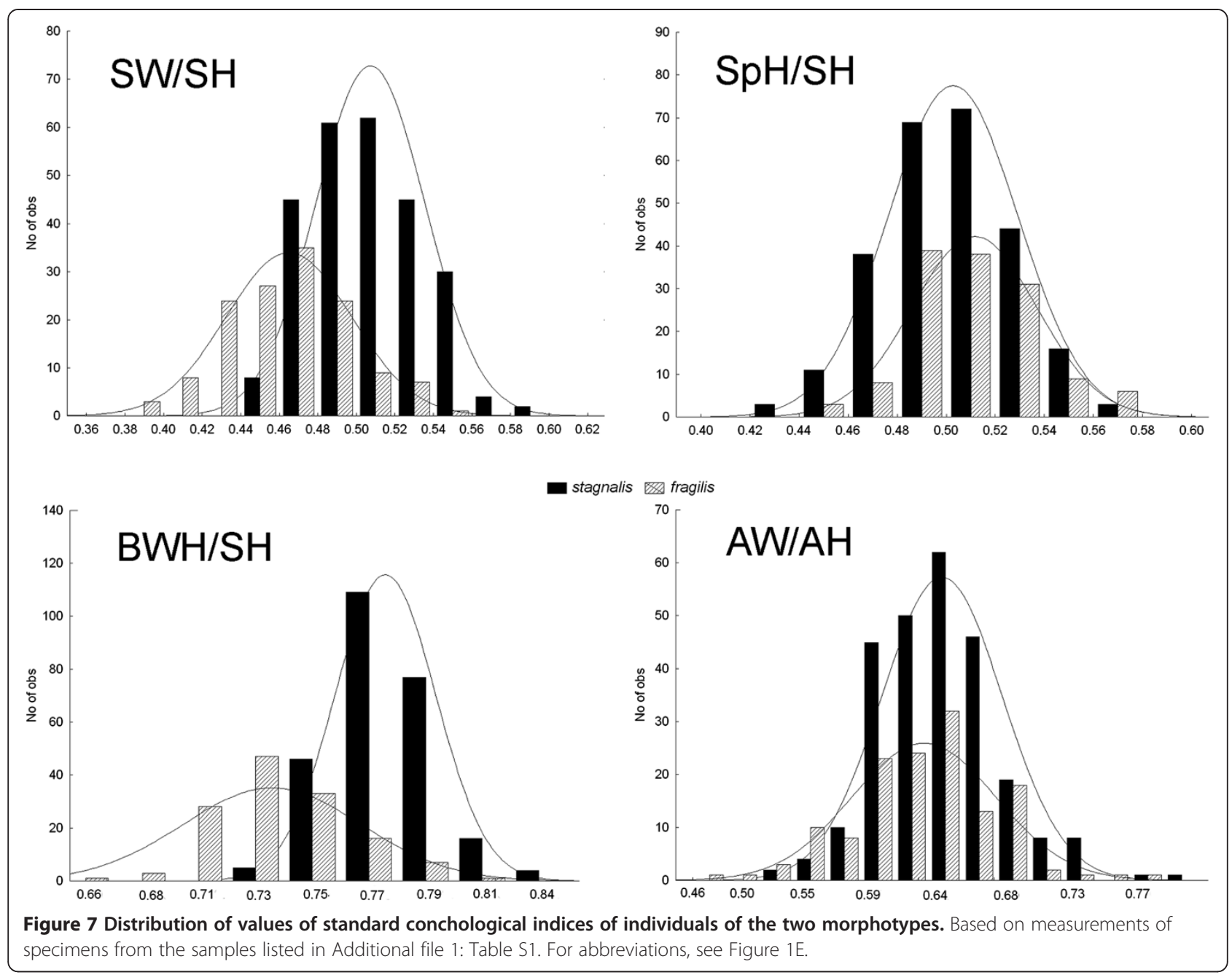

The results of two-sided ANOVA demonstrate that the type of waterbody (i.e. combination of water flow characteristics and hydroregime) influences shell morphology even if unique local conditions of a given habitat are taken into account (Table 7).

PC1 (=body size) proved to be related to ecological factors in both morphotypes: the differences in PC1 values among waterbodies of different types were significant (one-way ANOVA: L. stagnalis $F=16.342 ; p=0.00 ;$ L. fragilis $F=13.255 ; p=0.00$ ). The Scheffé test reveals that there is no significant difference between $\mathrm{PC} 1$ of populations collected from temporary and permanent waterbodies, but the PC1 scores in snails living in lotic habitats differ significantly from those in snails from lentic waterbodies ( $p \leq 0.03$ in both cases). Interestingly, the two morphotypes differ in the direction of relationship between body size and waterbody type: in L. fragilis lotic habitats harbour larger molluscs than lentic, while in $L$. stagnalis s. str., the opposite pattern is observed (oneway ANOVA: L. stagnalis $F=18.18 ; p=0.00 ;$ L. fragilis
$F=4.67 ; p=0.03)$. Besides, in lotic habitats, the range of body size variation in both morphs is clearly wider than in lentic ones (Figure 11).

A similar pattern is observed when $\mathrm{PC} 2$ is taken into account. In both morphospecies, the PC2 scores are significantly different between lotic and lentic habitats (one-way ANOVA: L. stagnalis $\mathrm{F}=16.227 ; \mathrm{p}=0.00 ; L$. fragilis $\mathrm{F}=4.923 ; \mathrm{p}=0.027$ ) and are not different between temporary and permanent waterbodies.

Shells of $L$. stagnalis s. str. develop slightly higher spire in stagnant waters than in under lotic conditions. In lakes and ponds, the mean value of $\mathrm{SpH} / \mathrm{SH}$ ratio (which moderately correlates with PC3 scores) is $0.50 \pm 0.03$, whereas in rivers and streams, $0.48 \pm 0.03$. This difference is in fact extremely weak but statistically significant $(F=9.40 ; p=0.002)$. The values of the aperture index (AW/AH) are the same in stangant and flowing waters $(F=1.50 ; p=0.22)$.

No significant differences in the conchological indices correlated with PC3 were found in L. fragilis from ecologically different habitats. 


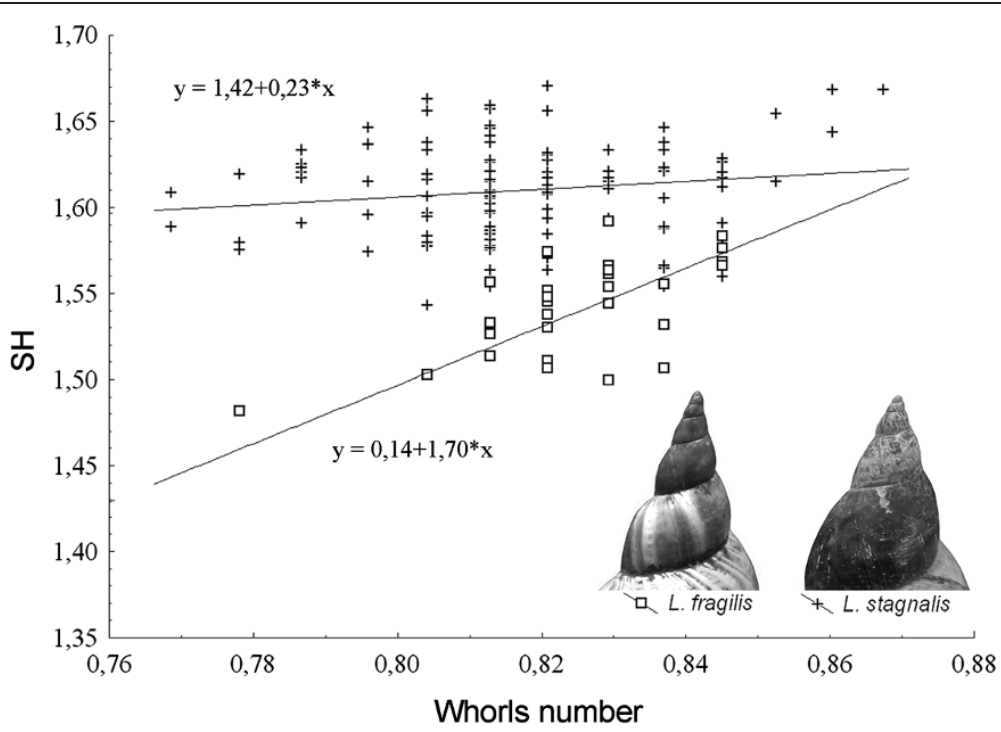

Figure $8 \mathrm{SH}$ values in specimens of the two morphotypes plotted against their whorls numbers (logarithmic scale). The samples are from the Tenis Lake. Omsk Region (see Additional file 1: Table S1). The regression equations and regression lines are provided. The slopes of the two lines are significantly different $(p=0.0001)$. Enlarged photographs of shell spires of fragilis and stagnalis show difference in their coiling rates.

\section{Discussion}

Taxonomic implications of obtained results

Intraspecific morphotypes were discovered in diverse families of pulmonate snails, both aquatic (Plam et al. 2008; Spyra and Strzelec 2013) and terrestrial (Gould 1968; Weigand et al. 2012). In some cases, however, the differences among them are being restricted to, for example, distinct patterns of the shell surface sculpture as it is observed in the planorbid snail Armiger crista (L., 1758) (Spyra and Strzelec 2013). In our case, we must deal with much greater external difference between morphotypes that corresponds to phenotypical distance observed between some 'true' species of lymnaeid snails or even exceeds it. For example, shell morphology in two species of the lymnaeid genus Aenigmomphiscola Kruglov et Starobogatov, 1981, whose distinctness was corroborated by molecular genetic techniques (Vinarski et al. 2011), is strikingly similar, and the phenetic distance between them is much lower than that separating the two morphotypes of L. stagnalis s. l. studied here (see Vinarski and Grebennikov 2012 for morphology of Aenigmomphiscola species). From the morphological point of view, the two morphotypes studied here appear to behave as two distinct entities more or less independent in the multivariate
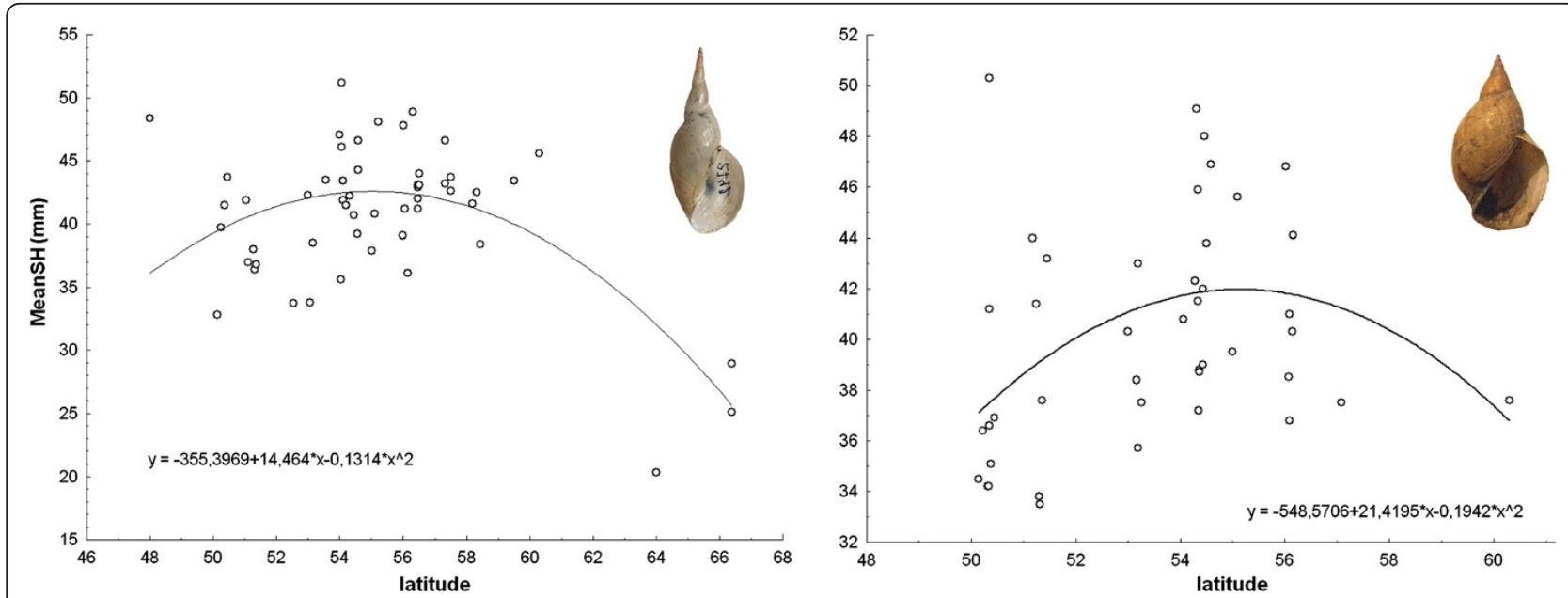

Figure 9 Relationships between geographical latitude and mean SH in the morphotypes L. fragilis (left) and L. stagnalis (right) in Western Siberia. Each point corresponds to a mean SH in a particular habitat. Statistics for regression equations is given in Table 4. 
Table 3 The effect of latitude on shell size estimates in the two morphotypes of $L$. stagnalis $s . I^{a}$

\begin{tabular}{lccccccc}
\hline & \multicolumn{3}{c}{ L. fragilis morphotype } & & \multicolumn{3}{c}{ L. stagnalis morphotype } \\
\cline { 2 - 3 } & Max SH & Mean SH & PC1 & & Max SH & Mean SH & PC1 \\
\hline Intercept & -419.65 & -355.4 & -58.75 & -577.62 & -548.57 & 54.15 \\
Latitude & 17.0 & 14.46 & 2.14 & 22.93 & 21.42 & -0.63 \\
$p$ & 0.000 & 0.000 & 0.000 & 0.126 & 0.02 & 0.01 \\
$F$ & 12.96 & 15.66 & 14.36 & 2.18 & 44.9 & 5.03 \\
$R^{2}$ & 0.34 & 0.39 & 0.36 & & 0.10 & 0.18 & 0.20 \\
\hline
\end{tabular}

${ }^{a}$ Significant values of $p$ are italicized.

space, therefore it is not surprising that some authors (Kruglov and Starobogatov, 1985, 1993; Kruglov 2005) regard them as full biological species.

Despite the absence of substantial molecular differences (Vinarski et al. 2012a), there are certain arguments in favour of the specific status of L. fragilis and L. stagnalis s. str.:

1. The ranges of distribution of the two morphotypes in Western Siberia do not overlap completely (see Figure 3). It may mean that there are some underlying genetic differences that determine their dissimilar adaptational abilities in relation to environmental factors known to vary geographically in this region. This supposed genetic distinctness may well be 'invisible' for investigators using certain standard and selectively neutral gene markers such as COI, cyt b, ITS-1 and so on. The so called speciation genes (Orr et al. 2004; Nosil and Schluter 2011), not identical, of course, with the most popular genetic markers, might have been involved in the process of divergence between $L$. fragilis and L. stagnalis $\mathrm{s}$. str.

2. Kruglov and Starobogatov (1985) reported that the results of the crossing experiments have shown that $L$. fragilis and L. stagnalis are reproductively isolated and, thus, may be acclaimed to be true 'biological' species. 3 . It is unlikely that the environmental conditions are responsible for the rise of the two morphs since these often co-occur and may be found to adjoin in a few square meters of bottom. Their ecological preferences are highly similar.

4. A significant difference between parameters of the regression equations describing shell growth in two morphs (see Figure 8 ) is considered by some authors as a good criterion for specific status in pulmonate snails (Diver 1939; Popov and Kramarenko 1994).

On the other hand, the negative arguments opposing the specific status of the two morphotypes are also strong and numerous.

1. The absence of any reliable molecular difference between $L$. fragilis and L. stagnalis s. str. ought to be contrasted with the previous results obtained by independent teams of investigators (Bargues et al. 2003; Puslednik et al. 2009; Schniebs et al. 2011; Vinarski et al. 2012a) that showed closely allied species or subspecies of Lymnaeidae described on the basis of phenotypical differences are perfectly distinguishable by means of the same molecular markers that failed to reveal any difference between the two morphs studied here. Sometimes, the molecular distance between conchologically similar genera (for example, between the genera Stagnicola Leach in Jeffreys, 1831 and Ladislavella B.

Dybowski, 1913 (=Catascopia Meier-Brook et Bargues, 2002)) exceeds that separating phenotypically distinct genera such as Lymnaea and Stagnicola (Vinarski 2012b; Vinarski et al. 2012b).

2. Kruglov and Starobogatov's (1985) conclusion that $L$. fragilis and L. stagnalis s. str. are reproductively isolated was questioned by (Mezhzherin et al. 2008), who concluded that this assumed isolation really does not exist. As (Korniushin 1996) mentions, the reality of the reproductive isolation between $L$. fragilis and $L$. stagnalis s. str. has not been confirmed by an independent researcher (s) and thus still awaits its corroboration.

3. The absence of a clear gap in variation of all continuous conchological characters between $L$. fragilis and L. stagnalis s. str. It is often stated that only sharp

Table 4 Multiple regression of the dependent and independent variables

\begin{tabular}{|c|c|c|c|c|c|c|c|c|}
\hline \multirow[t]{2}{*}{ Morphotype } & \multicolumn{4}{|c|}{ Regression statistics } & \multicolumn{4}{|c|}{ Significant variables } \\
\hline & $\mathrm{N}$ & $\mathrm{R}^{2}$ & $\mathrm{~F}$ & $p$ & Variable & $\mathrm{R}^{2}$ & $F$ & $p$ \\
\hline L. fragilis & 53 & 0.46 & 7.9476 & 0.000017 & Precipitation & 0.42 & 15.09 & 0.0003 \\
\hline \multirow[t]{2}{*}{ L. stagnalis } & 44 & 0.34 & 4.916 & 0.0026 & Longitude & 0.15 & 7.159 & 0.005 \\
\hline & & & & & Precipitation & 0.26 & 6.47 & 0.011 \\
\hline
\end{tabular}

First principal component (PC1) as the dependent variable and latitude, longitude, altitude, and five climatic indicators as the independent variables. PC1 explains $93.3 \%$ of the overall variation in L. fragilis and $91.6 \%$ in L. stagnalis s. str. Significant results are italicized. 
Table $\mathbf{5}$ The effect of latitude on conchological indices in the two morphotypes studied

\begin{tabular}{lccccc}
\hline Index & Intercept & Latitude & $\boldsymbol{p}$ value & $\boldsymbol{F}$ & $\boldsymbol{R}^{\mathbf{2}}$ \\
\hline L. fragilis morphotype & & & & \\
SW/SH & -1.11 & 0.06 & 0.000 & 24.28 & 0.49 \\
SpH/SW & 1.40 & -0.03 & 0.000 & 30.1 & 0.55 \\
BWH/SW & 0.20 & 0.02 & 0.000 & 25.67 & 0.51 \\
AW/AH & -0.885 & -0.06 & 0.000 & 60.94 & 0.71 \\
L. stagnalis morphotype & & & & \\
SW/SH & -0.98 & 0.06 & 0.27 & 1.36 & 0.06 \\
SpH/SW & 0.207 & -0.01 & 0.053 & 3.154 & 0.13 \\
BWH/SW & 0.290 & 0.02 & 0.37 & 1.03 & 0.05 \\
AW/AH & 2.864 & -0.09 & 0.012 & 4.98 & 0.20 \\
\hline
\end{tabular}

hiatus between recent species' morphology proves their reality (Tixier 2013). In conjunction with the absence of molecular support, continuity in variation of all conchological characters in the morphs (see Figure 7) is rather an argument against their specific status.

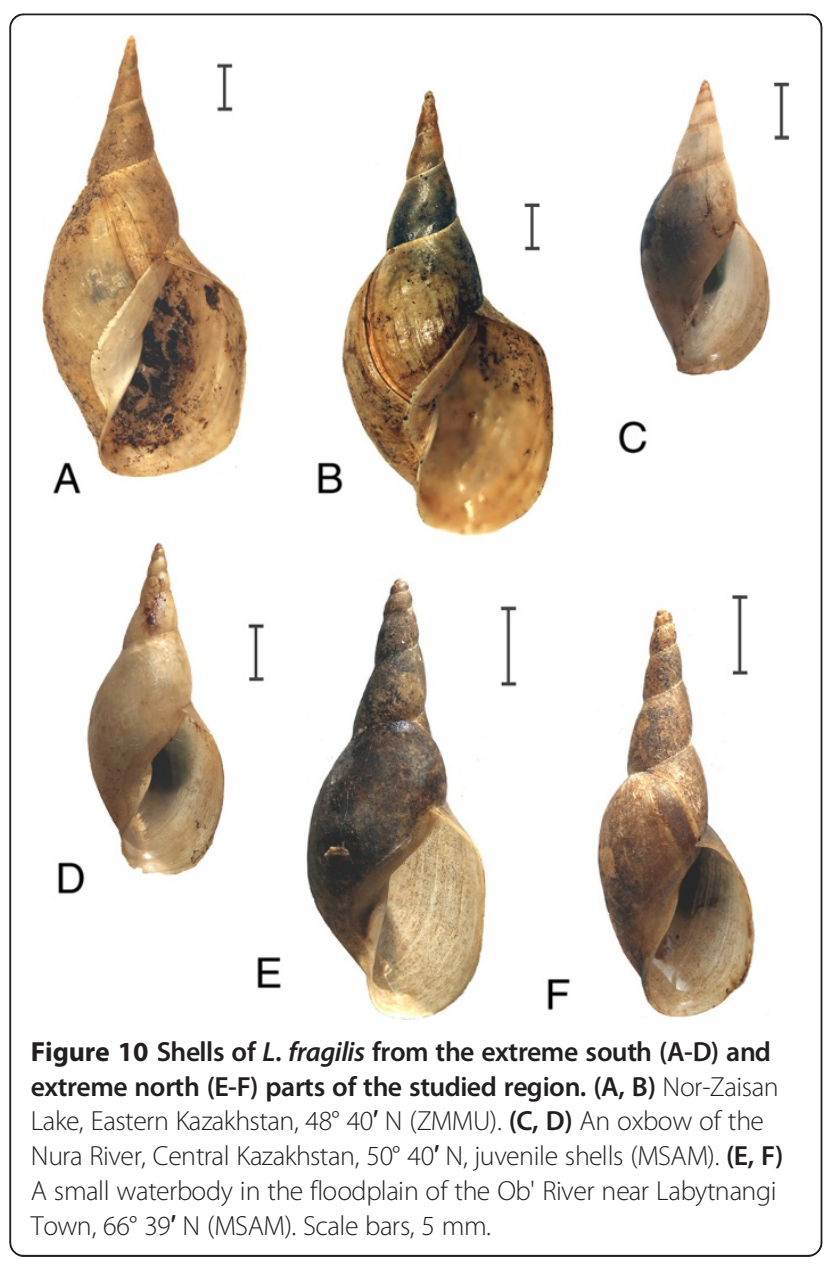

Table 6 Factor loadings of traits in the principal component analysis of shell variation in the morphospecies of $L$. stagnalis s. I

\begin{tabular}{lccc}
\hline Character & PC1 & PC2 & PC3 \\
\hline L. stagnalis s. str & & & \\
Whorls number & -0.133056 & 0.989007 & -0.062699 \\
SH & -0.981103 & -0.006697 & 0.158126 \\
SW & -0.955505 & -0.053539 & -0.177866 \\
SpH & -0.878451 & 0.068038 & 0.454748 \\
BWH & -0.978979 & -0.025853 & 0.028526 \\
AH & -0.957439 & -0.074609 & -0.166515 \\
AW & -0.909469 & -0.040563 & -0.269186 \\
\% variation explained & 76.67 & 14.19 & 5.26 \\
L. fragilis & & & \\
Whorls number & -0.524017 & -0.820303 & 0.224101 \\
SH & -0.979662 & -0.038352 & -0.165833 \\
SW & -0.945147 & 0.186589 & 0.130178 \\
SpH & -0.880820 & -0.241272 & -0.377257 \\
BWH & -0.959795 & 0.141084 & -0.088616 \\
AH & -0.944156 & 0.195684 & 0.105382 \\
AW & -0.902253 & 0.203292 & 0.265825 \\
\% variation explained & 79.00 & 12.39 & 4.67 \\
\hline
\end{tabular}

Possible mechanisms to explain the patterns of geographical variation in the great pond snail

The first attempt that I knew to investigate spatial patterns in the shell variation in L. stagnalis was undertaken by Kobelt (1871), who reported that absolute size of shell in the great pond snail in Central Europe decreases in south-north direction. This conclusion was not accompanied by sound biometrical analysis of data and, thus, it was mere an empirical observation without strong statistical support. The first author to apply statistical methods for study of geographic variation in the great pond snail was Terentiev 1970a). Contrary to the opinion of certain malacologists (Hubendick 1951; Russell-Hunter 1978), he demonstrated that geographical clines in the pond snail are real and statistically significant. However, both Kobelt and Terentiev dealt with L. stagnalis s. lato, without distinguishing the morphotypes.

In my previous work on this subject based on correlation analysis (Vinarski 2012a), I argued that there is a linear negative relationship between the latitude and body size both in L. stagnalis s. str. and L. fragilis. The aforementioned results have shown that this relationship is non-linear with the largest snails tending to occur in the forest-steppe waterbodies situated between $54^{\circ}$ and $58^{\circ}$ of latitude (see Figure 9). One can see here two good examples of so called U-shaped clines similar to numerous hump-shaped body size clines described in other taxa of 


\begin{tabular}{|c|c|c|c|c|}
\hline Variables & $d f$ & MS & $F$ & $p$ value \\
\hline \multicolumn{5}{|l|}{ L. stagnalis S. str } \\
\hline \multicolumn{5}{|l|}{ PC1 } \\
\hline Locality & 11 & 32.235 & 27.052 & 0.000 \\
\hline Type of waterbody & 2 & 42.950 & 36.044 & 0.000 \\
\hline Locality $\times$ waterbody type & 22 & 22.101 & 24.421 & 0.000 \\
\hline \multicolumn{5}{|l|}{ PC2 } \\
\hline Locality & 11 & 6.501 & 16.700 & 0.000 \\
\hline Type of waterbody & 2 & 7.476 & 19.202 & 0.000 \\
\hline Locality $\times$ waterbody type & 22 & 5.366 & 13.781 & 0.000 \\
\hline \multicolumn{5}{|l|}{ PC3 } \\
\hline Locality & 11 & 0.586 & 5.786 & 0.000 \\
\hline Type of waterbody & 2 & 0.560 & 5.529 & 0.004 \\
\hline Locality $\times$ waterbody type & 22 & 0.593 & 5.583 & 0.000 \\
\hline \multicolumn{5}{|l|}{ L. fragilis } \\
\hline \multicolumn{5}{|l|}{ PC1 } \\
\hline Locality & 11 & 21.27 & 46.200 & 0.000 \\
\hline Type of waterbody & 2 & 44.3 & 96.265 & 0.000 \\
\hline Locality $\times$ waterbody type & 22 & 20.4 & 44.325 & 0.000 \\
\hline \multicolumn{5}{|l|}{ PC2 } \\
\hline Locality & 11 & 3.912 & 23.423 & 0.000 \\
\hline Type of waterbody & 2 & 1.417 & 8.487 & 0.000 \\
\hline Locality $\times$ waterbody type & 22 & 4.248 & 25.436 & 0.000 \\
\hline \multicolumn{5}{|l|}{ PC3 } \\
\hline Locality & 11 & 0.509 & 5.534 & 0.000 \\
\hline Type of waterbody & 2 & 0.259 & 2.281 & 0.06 \\
\hline Locality $\times$ waterbody type & 22 & 0.500 & 5.446 & 0.000 \\
\hline
\end{tabular}

terrestrial invertebrates, e.g. in arthropods (Blanckenhorn and Demont 2004) and land snails (Terentiev 1970b). In L. stagnalis, significant decrease of body size with longitude has also been found.

Why do the lesser snails occur in the northern and the southern belts of the Western Siberian region given that the environmental conditions in these geographical extremes are drastically different? It is well known that the geographical latitude itself is an artificial factor invented rather for the sake of utility than for causal explanations (Hawkins and Diniz-Filho 2004). Typically, latitude is correlated with a plethora of bioclimatic variables that may be responsible for moulding molluscan shells (Goodfriend 1986). In the studied case, precipitation proved to be the main factor positively correlated with the body size (see Table 4). In some pulmonate snails, shell size tends to correlate positively with the annual rainfall (Heller 1979; Goodfriend 1986; Nishi and Sota 2007), thus I am inclined to think that high precipitation observed in Western Siberia between 54 and 60 latitudes (Figure 12) creates the most appropriate conditions for molluscs to grow longer and to reach the larger sizes. Much earlier, Terentiev (1970a) demonstrated that many species of terrestrial snails in Eastern Europe attain the maximum size in the intermediate latitudes thus forming hump-shaped clines. The author connected the largest sizes with the optimal (from the snails' point of view) conditions and coined the term 'Rensch rule' to designate this pattern (Terentiev 1970b; a quite distinct phenomenon is called "Rensch rule" in the modern literature, see Abouheif and Fairbairn, 1997; Blanckenhorn et al. 2006 for details).

The northern and the southern belts of Western Siberia suffer from rainfall decrease (see Figure 12) that may explain relative diminution of pond snails size in these latitudes. However, there is another factor of interest that is much more difficult to quantify using the bioclimatic data presented in the WorldClim database. I mean the shortage of the growth season, or the 'time horizon' (Gotthard 2001, 2004). In the north, the time horizon is reduced due to temperature shortage, whereas in the south it may become narrower because of desiccation of waterbodies to the end of hot summer (Rikhter 1963; Vinarski 2012a).

The pond snails and other temperate aquatic pulmonates typically stop to grow when the temperature sinks below some threshold value (Arakelova 1986). Similarly, they do not grow during summer aestivation caused by the waterbody desiccation. The simplest mechanistic explanation would suggest that the shorter growth season merely prevents the snails from becoming larger. However, the body size is the object of natural selection, and most ecologists believe that fitness increases continuously with final size (Gotthard 2004). Animals are thought to control their growth strategies accomodating themselves to changes in external conditions. A selectionist-type hypothesis to explain the U-shaped clines in the pond snails would assume that the molluscs can adjust parameters of their life histories and to maximize 'deliberately' their juvenile growth in order to mature earlier albeit at lesser size. Under conditions of the narrower time horizon, the lesser size is the 'optimal' one since it allows snails to start their reproduction before the short summer ends. Typically, a mature mollusc invests much more energy to reproduction than to somatic growth and, thus, the growth in adult snails declines abruptly (Gould 1968; Zotin 2009).

I have no experimental evidence for the selectionist hypothesis but it is possible to invoke the fact of geographical changes in shell proportions to support it. From the morphological point of view, the acceleration of sexual maturation relative to the rest of ontogeny may led to paedomorphic effects when the entire habitus of an animal becomes juvenilized (Stanley 1979). This is exactly that one may see when the 'northern' and 'southern' individuals of 


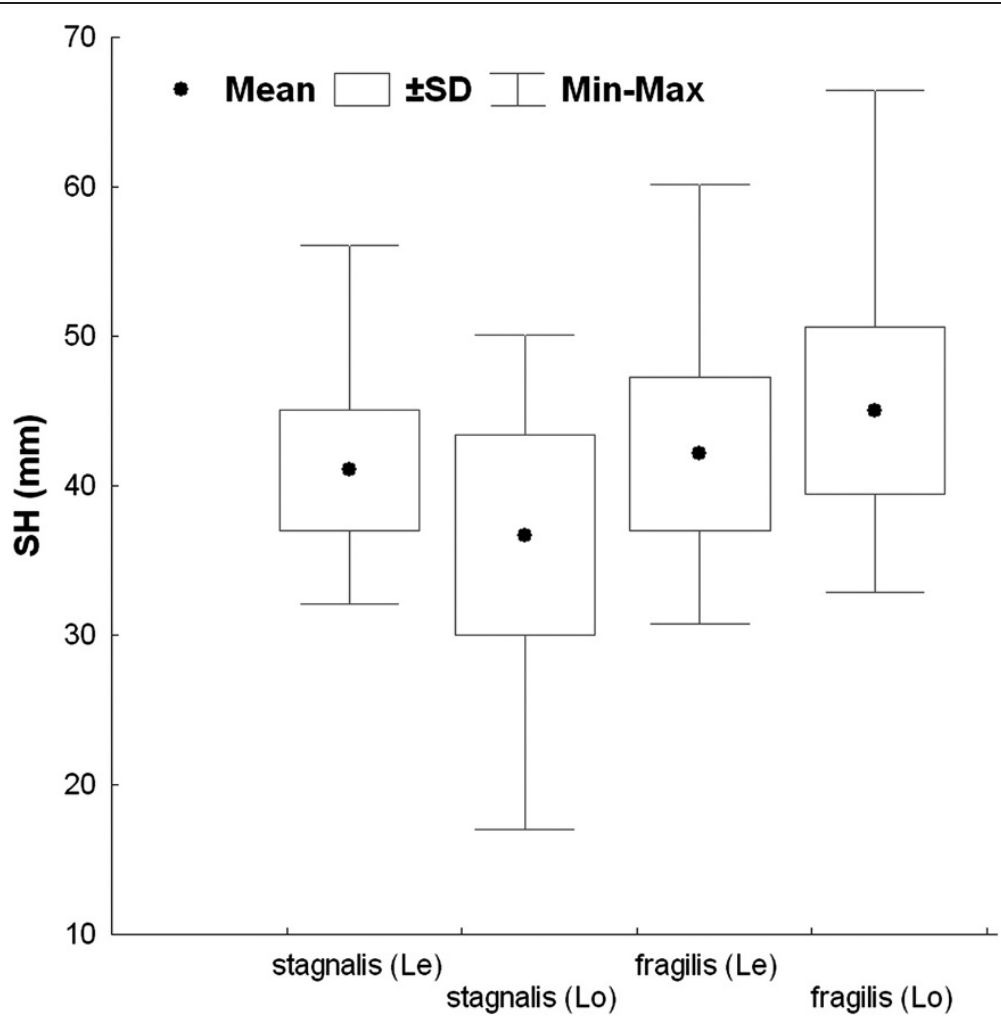

Figure 11 Shell size in L. fragilis and L. stagnalis s. str. from lentic (le) and lotic (lo) waterbodies in Western Siberia.

L. fragilis are compared. The juvenile snails of the southern populations are visibly more slender and high-spired than the adult ones (see Figure 10). Shell proportions in the 'southern' juveniles are similar to those characterizing the 'northern' adult snails; therefore, the latter have paedomorphic appearance. Following Gould (1968), one may suppose that it is a result of changing in parameters of the allometric growth of molluscan shells. Gould (1968)

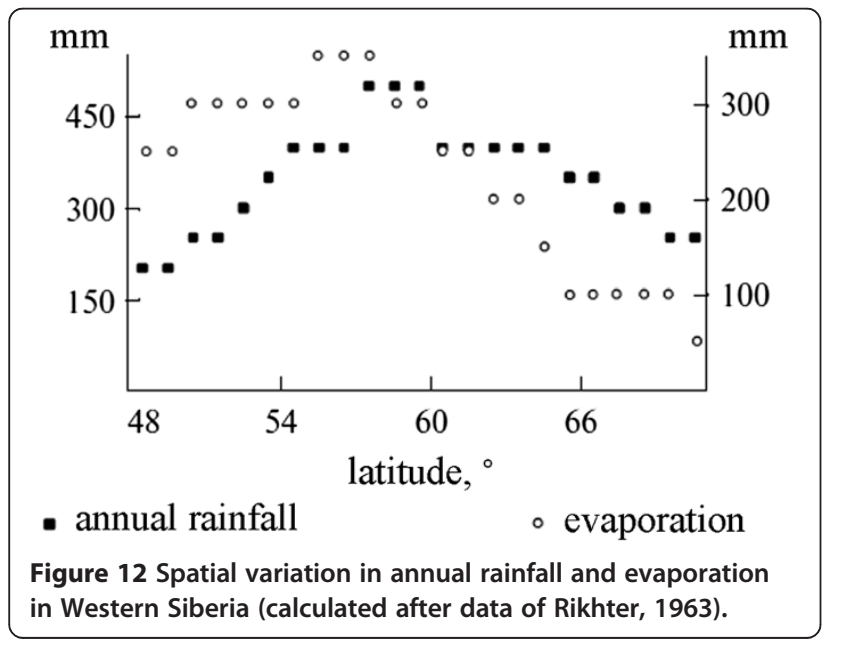

himself described some paedomorphic morphotypes in the land snails Poecilozonites bermudensis (Pfeiffer, 1845).

Significance of ecologically induced shell variation in the great pond snail

Numerous authors have tried to reveal the environmental factors that are able to control shell size and shape in lymnaeid snails (Zhadin 1923; Shileyko 1967; Arthur 1982; Pip 1983; Lam and Calow 1988; Wullschleger and Ward 1998). In most instances, a kind of direct environmental influence on shell traits has been registered, though it is rather difficult to ascertain whether the snails' morphological response has any hereditary basis (Arthur 1982). The extent of such influence of external factors on shell morphology has also been debatable. Some authors took the extreme position that each particular type of habitat generates its own 'ecological race' of Lymnaea characterized by certain peculiarities in shell size and proportions. For example, Zhadin (1923) could distinguish the 'lake' and 'pond' races of L. stagnalis based on shell morphometry data. Kruglov and Starobogatov (1993) accept two 'ecological subspecies' of L. stagnalis, one of them (nominotypical) is though to live in ponds and another, L. stagnalis turgida (Menke, 1840), is allegedly confined to oligotrophic lakes. 
Though my own results show that the conditions of living may modify conchological traits in L. stagnalis s. l., the magnitude of morphological differences between populations inhabiting different types of waterbodies is rather low and as such is not enough to consider them as distinct races having a specific external appearance. Briefly speaking, there are no well-defined 'lake,' 'river' or 'pond' phenotypes of the great pond snails, and, having examined many thousands of shells, I am still not able to determine a type of habitat of a given shell on the ground of its habitus. Peculiarities of a waterbody itself contribute to conchological variation (see Table 7) that may imply the effect of non-ecological factors such as spatial isolation of a habitat, genetic drift, etc.

The effect of water flow on shell morphology of freshwater molluscs was mostly assessed as significant (Baker 1928; Shileyko 1967; Lam and Calow 1988; Zieritz and Aldridge 2009). In my study, the water flow proved to be the only hydrological factor to influence appreciably the shell morphology in both morphotypes though the external differences between snails living in lotic and lentic habitats could not be perceived without statistical means. However, this factor is much more pronounced in large mountain lakes where L. stagnalis are living in shallow zone exposed to strong wave action. Under these conditions, the snails sometimes acquire ear-shaped shell with very short spire that looks dissimilar to the typical L. stagnalis shell (Geyer 1929; Shileyko 1967). I did not observe this in my materials due to the absence of deep mountain lakes in Western Siberia. Only a slight shortening of shell spire could be detected in L. stagnalis collected from lotic habitats as compared with those taken from stagnant waterbodies.

The absence of reliable conchological differences between snails from temporary and permanent habitats looks more problematic as in other lymnaeid species such differences were found (Chapuis et al. 2007). This topic requires further investigation.

\section{Conclusions}

Obviously, a study of museum samples containing dried shells only is not a proper way to solve the problem of taxonomic status of the morphotypes examined here. Nevertheless, the patterns of morphological variation revealed in my study hint that the usual taxonomic decision to lump all the conchogical variants under the same specific label (Hubendick 1951; Jackiewicz 1998) may well be an oversimplification. Seventy years ago, Simpson wrote: '...it is desirable that all distinguishable groups should be distinguished' in classifications (Simpson 1945: 23). Distinct morphotypes as such are therefore worth of formal recognition by systematists though the appropriate rank for their placement in the Linnaean hierarchy is very problematic to determine. The most obvious problem with taxonomic recognition of morphotypes is that they do not represent monophyla and, thus, do not constitute evolutionary significant units. Perhaps, a sort of new operational nomenclature, additional to the commonly accepted one (ICZN 1999), is required for designation of morphotypes and other similar supraspecific enitities lacking support from molecular phylogenetic studies. It seems, however, that the habitual hierarchical scheme 'species with its subspecies' dictated by the internationally adopted rules of nomenclature (ICZN 1999) is not fully adequate to describe the situation without loss of taxonomically relevant information.

Perhaps, we must discuss this case in the context of phenotypical polymorphism. Many years ago, Diver (1939: 101) defined polymorphism in non-marine snails as a situation when a species '...contains two or more distinct forms in the same colony'. One must find a discontinuity in variation of shell character(s) to acclaim a species to be polymorphic. Typically, shell polymorphism of this kind is rarely demonstrated by lymnaeids despite their great intrapopulation variation in shell shape, size and ever texture (Diver 1939; Hubendick 1951). In the studied instance, we are dealing with polymorphism of another sort that may be called 'statistical polymorphism'. It is characterized by statistically significant differences between mean values of all or some standard morphometric indices of syntopic morphs with parallel absence of phenotypical discontinuity (full hiatus) between them (see Table 2). The 'typical' individuals of each morphs may be visibly different (see Figure 1) but a portion of specimens in a mixed sample cannot be unambiguously ascribed to either of morphs due to the absence of hiatus.

\section{Additional file}

Additional file 1: Table S1. Samples of Lymnaea stagnalis s. I. used for multivariate analyses.

\section{Abbreviations}

$\mathrm{AH}$ : aperture height; AW: aperture width; $\mathrm{BWH}$ : body whorl height; $\mathrm{SH}$ : shell height; SpH: spire height; SW: shell width.

\section{Competing interests}

The author declares that he has no competing interests.

\section{Author information}

The author is an assistant professor of the Omsk State Pedagogical University (Department of Biology). His scientific interests include taxonomy, zoogeography and ecology of freshwater Mollusca (mainly gastropods) as well as host-parasite relationships in terrestrial ecosystems of Palearctic.

\section{Acknowledgements}

I thank Dr. Sergey S. Kramarenko (Ukraine, Nikolaev) for the discussion of variation patterns in pulmonate snails. The field sampling of $L$. stagnalis $\mathrm{s}$. I. in different waterbodies of the Urals and Western Siberia was assisted by Prof. Nikolay I. Andreev, Drs. Natalia P. Vinarskaya, Alfried V. Karimov (Omsk) and Dmitry M. Palatov (Moscow). I am grateful to all these persons. The financial support for this study was obtained from the Russian Fund for Basic Research (projects Nos. 12-04-98056-r_sibir_a and 14-04-01236) as well as from the Russian Ministry of Education and Science (project no. 6.1957.2014/K). 
Received: 2 May 2014 Accepted: 10 September 2014 Published online: 18 September 2014

\section{References}

Abouheif E, Fairbairn D (1997) A comparative analysis of allometry for sexual size dimorphism: assessing Rensch's rule. Am Nat 149:540-562

Andreyeva SI, Andreyev NI, Vinarski MV (1999) On the 'common' pond snail of the waterbodies of Omsk City. Natural Science and Ecology: Yearbook of the Omsk State Pedagogical University 4:145-152 [In Russian]

Andreyeva SI, Andreyev NI, Vinarski MV (2010) Key to freshwater gastropods of Western Siberia (Mollusca: Gastropoda). V. 1. Pulmonata. Fasc. 1. Families Acroloxidae and Lymnaeidae, Gastropoda. The authors, Omsk [In Russian]

Arakelova ES (1986) The effect of temperature on the duration of embriogenesis in freshwater pulmonates. Zh Obsch Biol 47(1):128-135 [In Russian]

Arthur W (1982) Control of shell shape in Lymnaea stagnalis. Heredity 49(2):153-161

Baker FC (1928) Influence of a changed environment in the formation of new species and varieties. Ecology 9:271-283

Bargues MD, Horák P, Patzner RA, Pointier JP, Jackiewicz M, Meier-Brook C, Mas-Coma S (2003) Insights into relationships of Palearctic and Nearctic lymnaeids (Mollusca: Gastropoda) by rDNA ITS-2 sequencing and phylogeny of stagnicoline intermediate host species of Fasciola hepatica. Parasite 10:243-255

Blanckenhorn WU, Demont M (2004) Bergmann and converse Bergmann latitudinal clines in Arthropods: two ends of a continuum? Integr Comp Biol 44:413-424

Blanckenhorn W, Stillwell R, Young K (2006) When Rensch meets Bergmann: does sexual size dimorphism change systematically with latitude? Evolution 60:2004-2011

Bookstein FL (1982) Foundations of morphometrics. Annu Rev Ecol Syst 13:451-470

Chapuis E, Trouve S, Facon B, Degen L, Goudet J (2007) High quantitative and no molecular differentiation of a freshwater snail (Galba truncatula) between temporary and permanent water habitats. Mol Ecol 16:3484-3496

Diver C (1939) Aspects of the study of variation in snails. J Conch 21(4-5):91-141

Geyer D (1929) Die Molusken des Bodenseestrandes. Zool Jahr. Abt Syst Ökol Geogr Tiere 58:135-172

Goodfriend GA (1986) Variation in land-snail shell form and size and its causes: a review. Syst Zool 35(2):204-223

Gotthard K (2001) Growth strategies of ectothermic animals in temperate environments. In: Atkinson D, Thorndyke M (ed) Animal developmental ecology. BIOS Sci. Publ, Oxford

Gotthard K (2004) Growth strategies and optimal body size in temperate Pararginii butterflies. Integr Comp Biol 44:471-479

Gould SJ (1968) Ontogeny and the explanation of form: an allometric analysis. J Paleont Suppl 2:81-98

Gould SJ, Johnston RF (1972) Geographic variation. Annu Rev Ecol Syst 3:457-498

Hammer Ø, Harper DAT, Ryan PD (2001) PAST: palaeontological statistics software package for education and data analysis. Paleontologica Electronica 4(1):1-9

Hawkins BA, Diniz-Filho JA (2004) 'Latitude' and geographic patterns in species richness. Ecography 27(2):268-271

Heller J (1979) Distribution, hybridization and variation in the Israeli land snail Levantina (Pulmonata : Helicidae). Zool J Linn Soc 67:115-148

Hubendick B (1951) Recent Lymnaeidae. Their variation, morphology, taxonomy, nomenclature and distribution. Kung Svensk Vetens Hand. Fjärde Ser 3(1):1-223

ICZN (1999) International Code of Zoological Nomenclature. Fourth edition. The International Trust for Zoological Nomenclature, London

Jackiewicz M (1998) European species of the family Lymnaeidae (Gastropoda, Pulmonata, Basommatophora). Genus 9(1):1-93

Kobelt W (1871) Zur Kenntniss der europäischen Limnäen. II. L. stagnalis Linné Malakozool Blätter 18:108-119

Korniushin AV (1996) Bivalve molluscs of the superfamily Pisidioidea in the Palaearctic region. Fauna, systematics, phylogeny. Kiev [In Russian]

Kruglov ND (2005) Lymnaeid snails of Europe and Northern Asia. Smolensk State Pedagogical University Press, Smolensk [In Russian]

Kruglov ND, Starobogatov YI (1985) Methods of experimental hybridization and some results of its applications in the taxonomy of Lymnaeidae. Malac Rev 18:21-35

Kruglov ND, Starobogatov YI (1993) Annotated and illustrated catalogue of species of the family Lymnaeidae (Gastropoda Pulmonata Lymnaeiformes) of Palaearctic and adjacent river drainage areas. Part I Ruthenica 3(1):65-92

Lam PKS, Calow P (1988) Differences in the shell shape of Lymnaea peregra (Müller) (Gastropoda: Pulmonata) from lotic and lentic habitats: environmental or genetic variance? J Moll Stud 54:197-207
Locard A (1893) Coquilles des eaux douces et saumâtres de France. Desctiption des familles, genres et espéces, Alexandre Rey, Lyon

Mezhzherin SV, Garbar AV, Korshunova ED, Zhalay El (2008) The analysis of morphological and genetic variation of the snail, Lymnaea stagnalis s. 1. (Gastropoda, Lymnaeidae), in Ukraine. Vestnik Zool 42(4):339-345 [In Russian]

Nishi H, Sota T (2007) Geographical divergence in the Japanese land snail Euhadra herklotsi inferred from its molecular phylogeny and genital characters. Zool Sci 24(5):475-485

Nosil P, Schluter D (2011) The genes underlying the process of speciation. Trends Ecol Evol 26(4):160-167

Orr HA, Masly JP, Presgraves DC (2004) Speciation genes. Curr Opinions Gen Dev 14:675-679

Piaget J (1929) L'Adaptation de la Limnaea stagnalis aux milieux lacustres de la Suisse romande. Ėtude biometrique et génétique. Rev Suiss Zool 36(17):1-268

Pip E (1983) Variability in North American Lymnaea stagnalis. Nautilus 97(2):77-79

Plam M, Jørgensen A, Kristensen TK, Madsen H (2008) Sympatric Biomphalaria species (Gastropoda: Planorbidae) in Lake Albert, Uganda, show homoplasies in shell morphology. Afr Zool 43(1):34-44

Popov VN, Kramarenko SS (1994) On interspecific differences in shell growth in land snails of the genus Brephulopsis (Gastropoda; Bulimindae) of Crimea. Vestnik Zool 28(4-5):3-7 [In Russian]

Puslednik L, Ponder WF, Dowton M, Davis AR (2009) Examining the phylogeny of the Australasian Lymnaeidae (Heterobranchia: Pulmonata: Gastropoda) using mitochondrial, nuclear and morphological markers. Mol Phylog Evol 52:643-659

Rikhter GD (ed) (1963) Western Siberia. Soviet Academy of Sciences Press, Moscow Russian

Russell-Hunter WD (1978) Ecology of freshwater pulmonates. In: Fretter V, Peake J (ed) Pulmonates: systematics, evolution and ecology. Vol. 2A. Academic Press, Londin etc

Schniebs K, Glöer P, Vinarski M, Hundsdoerfer A (2011) Intraspecific mophological and genetic variability in Radix balthica (Linnaeus 1758) (Gastropoda: Basommatophora: Lymnaeidae) with morphological comparison to other European Radix species. J Conch 40(6):657-678

Shileyko AA (1967) On variability of lymnaeid (Gastropoda, Mollusca) of the Kola Peninsula. Gidrobiol Zh 3:77-80 [In Russian]

Simpson GG (1945) The principles of classification and a classification of mammals. Bull Am Mus Nat Hist 85:1-350

Spyra A, Strzelec M (2013) Occurrence and morphological variability of Gyraulus crista (Gastropoda: Pulmonata: Planorbidae) on different types of substratum in woodland ponds. Biologia (Bratislava) 68(4):679-686

Stanley SM (1979) Macroevolution: pattern and process. W.H. Freeman and Co, San Francisco

Starobogatov YI, Bogatov W, Prozorova LA, Saenko EM (2004) Molluscs. In: Tsalolikhin SY (ed) Key to the freshwater invertebrates of Russia and adjacent countries, vol 6. Nauka, Sankt-Petersburg Russian

Terentiev PV (1970a) Geographic variation of the shell of the pond snail L. stagnalis. Vestnik LGU biol ser 4(21):146-154 [In Russian]

Terentiev PV (1970b) The effect of climatic temperature on shell size in terrestrial mollusks. Zool Zh 49(1):5-10 [In Russian]

Tixier MS (2013) Statistical approaches for morphological continuous characters: a conceptual model applied to Phytoseiidae (Acari: Mesostigmata). Zool Scr 42:327-334

Vinarski MV (2010) A historical outline of study of Siberian freshwater malacofauna (end of XVIII - middle of XX centuries). Ruthenica 20(1):45-67 [In Russian]

Vinarski MV (2012a) Geographic variability in freshwater mollusks. Biol Bull Rev 2(5):390-399

Vinarski MV (2012b) The lymnaeid genus Catascopia Meier-Brook et Bargues, 2002 (Mollusca: Gastropoda: Lymnaeidae), its synonymy and species composition. Inv Zool 9(2):91-104

Vinarski MV, Grebennikov ME (2012) A review of the species of the genus Aenigmomphiscola Kruglov et Starobogatov, 1981 (Gastropoda: Pulmonata: Lymnaeidae). Ruthenica 22(2):159-170

Vinarski MV, Serbina EA (2012) Distribution and quantitative characteristics of common species of pond snails of the subgenera Peregriana and Radix (Mollusca: Gastropoda: Lymnaeidae) in waterbodies of the south of Western Siberia. Inland Water Biol 5(2):192-198

Vinarski MV, Schniebs K, Glöer P, Hundsdoerfer AK (2011) The taxonomic status and phylogenetic relationships of the genus Aenigmomphiscola Kruglov and Starobogatov, 1981 (Gastropoda: Pulmonata: Lymnaeidae). J Nat Hist 33-34:2049-2068 
Vinarski MV, Schniebs K, Glöer P, Hundsdoerfer A (2012a) Preliminary phylogeography of Lymnaea stagnalis: are there cryptic species of the great pond snail? In: Abstracts of the XI International Congress on Medical and Applied Malacology. Sociedade Brasileira de Malacologia, Rio de Janeiro

Vinarski MV, Schniebs K, Glöer P, Son MO, Hundsdoerfer A (2012b) The steppe relics: taxonomic study on two lymnaeid species endemic to the former USSR (Gastropoda: Pulmonata: Lymnaeidae). Arch Molluskenk 141(1):67-85

Weigand AM, Götze MC, Jochum A (2012) Outdated but established?

Conchologically driven species delineations in microgastropods (Carychiidae, Carychium). Org Div Evol 12(4):377-386

Westerlund CA (1885) Fauna der in der Paläarktischen Region lebenden Binnenconchylien. V. Fam. Succineidae, Auriculidae, Limnaeidae, Cyclostomidae und Hydrocenidae, Ohlsson, Lund

Wullschleger EB, Ward PI (1998) Shell form and habitat choice in Lymnaea. J Moll Stud 64:402-404

Zhadin VI (1923) Variation of Limnaea stagnalis L. in waterbodies lying in vicinity of Murom Town. Russkiy Gidrobiol Zh 2(5-7):97-106 [In Russian]

Zieritz A, Aldridge DC (2009) Identification of ecophenotypic trends within three European freshwater mussel species (Bivalvia: Unionoida) using traditional and modern morphometric techniques. Biol J Linn Soc 98:814-825

Zotin AA (2009) Individual growth of Lymnaea stagnalis (Lymnaeidae, Gastropoda): II. Late postlarval ontogeny. Biol Bull 36(6):591-597

doi:10.1186/s40555-014-0069-4

Cite this article as: Vinarski: A comparative study of shell variation in two morphotypes of Lymnaea stagnalis (Mollusca: Gastropoda:

Pulmonata). Zoological Studies 2014 53:69.

\section{Submit your manuscript to a SpringerOpen ${ }^{\circ}$ journal and benefit from:}

- Convenient online submission

- Rigorous peer review

- Immediate publication on acceptance

- Open access: articles freely available online

- High visibility within the field

- Retaining the copyright to your article

Submit your next manuscript at $\gg$ springeropen.com 